\title{
Characterisation of Young People According to Their Financial Attitudes and Behaviours - A Survey on the Financial Behaviour and Attitudes of Students in Higher Education*
}

\author{
Boglárka Zsótér ${ }^{1}$, Erzsébet Németh ${ }^{2}$ \\ ${ }^{1}$ Corvinus University of Budapest, Budapest, Hungary \\ ${ }^{2}$ Budapest Metropolitan University, Budapest, Hungary \\ Correspondence: Boglárka Zsótér, Corvinus University of Budapest, Budapest, Hungary.
}

Received: September 29, 2017

doi:10.11114/afa.v4i1.2780
Accepted: November 2, 2017

Available online: November 8, 2017

URL: https://doi.org/10.11114/afa.v4i1.2780

\begin{abstract}
Financial markets and products are becoming increasingly complex. This trend goes hand in hand with an ever-deepening financial information gap. Researchers and marketers should get acquainted with behaviour, habits and attitudes of future's consumers better. One of the key target groups in exploring this area includes secondary school and university students, as most of the financial education programmes address them. The aim of this study to find out young adults' characteristics regarding their financial behaviour and attitudes. By segmenting and describing Hungarian undergraduates according to their financial attitudes, the present study sets out to contribute to the success of financial educational programmes, initiated by either the public sector (financial education) or the business sector, with the aim to enhance the level of financial literacy. Based on the database of 2070 respondents, using principal component analysis and K-means clustering, we found that the young people can be categorised into three groups: (1) conservatives, (2) rebels and (3) experienced. The distinct differences in the attitudes and experiences of the three groups suggest that their financial education should be based on different foundations, which is worth considering when developing the relevant curricula.
\end{abstract}

Keywords: young adults, financial behaviour, financial attitude, financial experiences, financial literacy, consumer finance

\section{Introduction}

The aim of this study to find out young adults' characteristics regarding their financial behaviour and attitudes. By segmenting and describing Hungarian undergraduates according to their financial attitudes, the present study sets out to contribute to the success of financial educational programmes, initiated by either the public sector (financial education) or the business sector, with the aim to enhance the level of financial literacy. Financial behaviour of young adults is an important research topic, well worth considering from various aspects (Zsótér, 2017). Since the financial crisis in 2008 the investigation of financial literacy-especially its components (personality, attitudes, behaviour etc.) -is in the limelight. Modern economics have recognized that in order to effectively forecast financial and economic processes it is primordial to understand the attitudes of the members of society toward finances, as well as the characteristics of various social group sharing the same views and behaviours (Németh \& Zsótér, 2017). Young adults face crucial predicaments and have to handle sophisticated financial decisions at every stage of their life cycle (Sundarasen \& Rahman, 2017).

Money, together with the practical issues of handling and using it, is part and parcel of consumers' everyday life, however, we tend to relate to it in different ways. Economists, psychologists, sociologists and anthropologists have always been interested in the attitudes towards money and finances. Financial products are becoming increasingly complex and individual needs are also changing and growing (Habschick et al., 2007; Botos, 2012). The 2008 financial crisis has not spared Hungary either but has brought to the surface the shortcomings in the financial literacy of the population. The lack of knowledge in the retail sector mostly resulted in taking higher debt-related risks that went beyond what people could

${ }^{*}$ This work was created in commission of the National University of Public Service under the priority project KÖFOP-2.1.2-VEKOP-15-2016-00001 titled "Public Service Development Establishing Good Governance" and the Budapest Metropolitan University. 
afford and, eventually, in excessive indebtedness. The clearest example of this is provided by people with a foreign currency loan (Luksander et al., 2014). The root cause of the 2008 recession can also be linked to the acceleration of product innovation in the financial sector (Béres \& Huzdik, 2012). These developments take place in an environment which can be described by inadequate financial literacy among young people (Chen - Volpe, 1998; Volpe - Chen - Liu, 2006), therefore, the development of financial literacy has become indispensable. There is increased focus on financial literacy in Hungary also (Béres \& Huzdik, 2012; Zsótér \& Nagy, 2012; Béres et al., 2013). One of the key target groups in exploring this area includes secondary school pupils and young adults, as most of the financial education programmes address them.

\section{Literature Review}

In Hungary, the National Bank was the first to develop a comprehensive definition which includes several components of the concept of financial literacy: "A level of financial knowledge and skills that enables individuals to identify the fundamental financial information required to make their conscious and prudent decisions; and after the acquisition of identified data allows them to interpret said data, make decisions on their basis, all the while assessing potential future financial and other consequences of their decisions."(National Bank of Hungary, 2008; Luksander et al., 2014). Certain studies have shown that financial education is not sufficient for providing adequate information and developing skills, since the attitudes acquired in the family have a greater impact on the future financial behaviour of young people (for instance the propensity to save and take risks) than the knowledge acquired in formal schooling (Hanti, 2011). Hence we have to get deeper knowledge about financial attitudes and behaviours of young adults.

In the majority of studies, there is no distinct separation of financial attitudes and money attitudes (Goldberg \& Lewis, 1978; Yamauchi \& Templer, 1982; Furnham, 1984; Tang, 1992; Nagy \& Tóth, 2012; Sundarasen \& Rahman, 2017). Some authors, however, choose to approach financial attitudes from the direction of management and use of money (e.g. Furnham, 1999; Sundarasen \& Rahman, 2017; Klontz \& Britt, 2012; Inseng \& Teichert, 2016). Several authors research this area by exploring attitudes towards credit (e.g. Norvilitis and Mendes-Da-Silva, 2013; Khare, 2016). The importance of researching financial attitudes is supported by the fact that the treatment of money is hardly rational, but rather governed by often unrecognised emotional forces (Forman, 1987).

Goldberg and Lewis (1978) distinguished three groups of consumers on the basis of their money attitudes: Autonomy worshippers hoard money to mitigate their sense of discomfort and vulnerability. Security collectors, with their money, strive to avoid material damage caused by the changes in society and the environment. Power grabbers, in contrast, wish to acquire other people's attention and admiration by possessing money. Forman (1987) adds to this typology by introducing the group of players, who associate making money with an intense feeling of excitement and other emotions (e.g. poker or roulette).

Yamauchi and Templer (1982) define money attitude as a multidimensional concept, which includes the following: 1. symbol of power and prestige, 2. means of accumulation, 3. source of distrust, 4. phenomenon leading to anxiety. Durvasula and Lysonski's research (2010) of young people discarded the second dimension (means of accumulation) due to the characteristics of this age group. They found that young consumers in China tended to see money as the symbol of power and prestige, which aided self-expression. Several researchers used one or more dimensions from the multidimensional money-attitude scale of Yamauchi and Templer (1982), discussing them together with other variables. Bhardwaj and Bhattacharjee (2010) also applied the dimensions of power-prestige and anxiety when examining the repayment of loans and the issue of financial default. Their results show that the most important factors of non-performance are income and anxiety about money. People with a higher level of anxiety are more prone to non-performance than those who see money as a means to power and prestige. Obviously a lower income level is more likely to be coupled with anxiety. Kahne (2016) also used Yamauchi and Templer's MAS scale to research the relationship between money attitudes and compulsive buying behaviour. Kahne's (2016) results suggest that compulsive buying behaviour is influenced by money attitudes, namely by power and price sensitivity.

When discussing money attitudes, we should also mention the relationship between money and materialism. According to Richins and Dawson (1992), strong materialism implies positive money attitudes. Christopher et al. (2004) came to the conclusion that consumers with a strong materialistic attitude are less capable of saving/putting money aside for incidental expenditures in the future and make savings in general. Their results show that apart from financial attitudes, materialism also influences the previously discussed elements of financial behaviour. According Rimple (2017) materialism were found to be positively related to power-prestige sub-dimension of money attitude. Material happiness sub-dimension of materialism found to be negatively correlated to retention time, distrust and anxiety sub-dimensions. Based on results of Wang and Krumhuber (2016) importance of money is positively correlated with materialism. They assessed that the love and importance attached to money positively predicted the tendency to construe social relationships based on instrumentality.

Another approach to financial attitudes is Furnham's (1984) MBBS (Money Beliefs and Behaviours Scale) which 
identifies six factors in terms of the attitude towards money. These are the following: obsession, power, retention, security, inadequacy and effort/ability. Christopher et al. (2004) also followed Furnham's (1984) approach, but instead of the original 60 items of the scale, they grouped only 18 items into four factors: inadequacy of money, self-aggrandizement, conservative approach to money and negative emotions toward money. Masuo et al. (2004) also adapted Furnham's (1984) scale to set up their three factors regarding money attitude: power/prestige, security and financial modesty. According to Allen et al. (2007), the most commonly used money attitude scale is Furnham's MBBS scale.

Overall, we can conclude that academic discourse and research addresses the study of financial behaviour and money attitudes through several dimensions. The various scales often overlap and we can also find attempts to further explore and understand certain sub-dimensions within a definition.

\section{Methodology}

The target group of the research was represented by young adults (the 18-25 age group) studying various disciplines in higher education. They are in the phase of life when they start to be more and more undependent from their parents and usually they gain their first work experience as well. Financial issues are increasingly relevant in this life stage. The sample base consisted of two institutions of higher education which participated in the Financial Literacy Research, the Budapest University of Applied Sciences and the University of Szeged, with a combined total of nearly 38,000 students. 5.5 per cent of these students (2,090 respondents) filled out the questionnaire. After cleaning the database, 2,070 records were left for analysis, i.e. that was the number of validly completed questionnaires that could be used for assessment. Our questionnaire survey was conducted on the website www.penzugyikultura.hu and our target group was made up of undergraduates. The sample of 2,070 students represents the young adults studying in Hungarian higher education, regarding age, sex and major.

The questionnaire was structured into several sections, including for example questions about the students' income, set of objectives, behaviour towards financial products, financial knowledge, saving and investment behaviour and their sources of information.

We based our statements on financial attitudes and behaviour on certain items from Furnham's (1984) Money Attitude Scale, Yamauchi and Templer's (1982) Money Attitude Scale (MAS) and the financial literacy, attitude and behaviour scale by Danes et al. (1999). Responses to statements were expressed on a 7-point Likert Scale where 1 is "I do not agree at all" and 7 is "I agree completely".

We set out to characterise young people according to their financial behaviour and attitudes, for which we applied the method of cluster analysis, because we assumed that our target group was not homogeneous in terms of the variables used. First we conducted Principal Component Analysis to get acquainted with the structure of associated variables and to reduce the number of variables. Following the factor analysis of the survey's statements on financial attitude and behaviour, we formed groups by K-means clustering. We chose K-means clustering because this method can handle a large number of data points (Sajtos \& Mitev, 2007). In this case K-means clustering aims to partition 2070 observations into3 clusters in which each observation belongs to the cluster with the nearest mean.

The three clusters were characterised by various variables using cross tabulation in the case of non-metric variables, and using analysis of variance in the case of metric variables. In the results section we provide the characterisation of the three clusters based on the above mentioned methods.

\section{Results}

Undergraduates were segmented according to statements on financial attitudes, which we then grouped using the principal component analysis. This then served as the basis of any further analyses. Financial attitudes are grouped into four factors: awareness, attitudes towards loans, risk-orientation, moral values. Using the average values of the factors, first we applied hierarchical clustering to determine the number of clusters. This method divided the sample into three groups. Next we formed groups with the help of K-means clustering. The characteristics of the three clusters are shown in Table 1.

Table 1. The characteristics of the three clusters along the main factors

Source: own editing

\begin{tabular}{lccc}
\hline Dimensions of financial attitude & Cluster 1 & Cluster 2 & Cluster 3 \\
\hline Negative attitude towards loans & Highest (5.98) & Medium (4.67) & Lowest (3.73) \\
Risk taking & Lowest (1.65) & Highest (3.84) & Low (2.1) \\
Moral values & High (6.33) & Lowest (5.48) & Highest (6.57) \\
\hline
\end{tabular}

The figures show that the first and third clusters are characterised by a high level of awareness, low risk-taking and strong moral values, but are different in terms of their attitude towards loans: the first cluster is the most negative and the third is the most positive when it comes to loans. The second cluster has a lower level of awareness, greater risk appetite and lower moral values compared to the first and the third, while their attitudes towards loans are not fully established. 


\subsection{Demographics of the Three Clusters}

The average age of young people in the first cluster is 22.30 years. The average age of those in the second group is fairly close to the first (22.33 years), while the third cluster has the highest average age (23.12 years). Since our survey population comes from the 18-25 age group, we did not expect large differences in this respect. In terms of family status, the first two segments show similarities with $31.7 \%$ having a partner and $32 \%$ living together with their partner in the same household. In the third segment, $40 \%$ live together with their partner, which is the highest ratio among the three groups. Respondents with children are also represented in the largest proportion in the third group. $4.5 \%$ have one or more children in the first cluster, with $5.6 \%$ and $8.3 \%$ in the second and third respectively.

When probing about their living arrangements, we wanted to find out whether the respondents live together with their parents and if not, where (with relatives, halls of residence, rented accommodation, own home). $47.5 \%$ of those in the first cluster live with their parents and the second group is also characterised by the same ratio. We got a similar picture regarding those living in their own home: $15 \%$ in the first cluster and $15.3 \%$ in the second. The ratios of the third group are different from the first two, since here less students live with their parents $(42.6 \%)$ and more have their own home $(21.7 \%)$.

\subsection{Income and Income Sources}

The average net monthly income in EUR in the three groups is as follows: Cluster 1: EUR 219 Cluster 2: EUR 239 Cluster 3: EUR 283. Students have the following potential sources of income: pocket money, student grants, student loans, salary, self-employed activity (e.g. enterprise), social benefits and other sources. The distribution (\%) of income sources in the three groups are shown in Table 2.

Table 2. Ratios of income sources in the three clusters (\%)

\begin{tabular}{llll}
\hline Income source & Cluster $\mathbf{1}$ & Cluster 2 & Cluster 3 \\
\hline Pocket money & 33.62 & 37.64 & 23.49 \\
Student grant & 13.15 & 9.28 & 11.35 \\
Student loan & 2.02 & 3.99 & 5.43 \\
Salary & 37.27 & 33.41 & 43.95 \\
Self-employment & 5.09 & 7.22 & 7.55 \\
Social benefits & 4.04 & 2.96 & 4.16 \\
Other & 4.82 & 5.08 & 4.06 \\
\hline
\end{tabular}

Source: own editing

According to the table, the major sources of students' income are salary and pocket money. The weight of the two, however, varies considerably by clusters. In the first and third clusters, the main source of income is salary (37.27\% and $43.95 \%$ respectively), while in the second group pocket money $(37.64 \%)$. The ratio of student grants as a source of income is the highest in the first cluster $(13.15 \%)$ and lowest in the second cluster $(9.28 \%)$. Student loans have the lowest ratio in Cluster $1(2.02 \%)$ and the highest in Cluster $3(5.43 \%)$.

\subsection{Previous and Current School and Work Experience}

When it comes to previous school experience, we found that $28.1 \%$ of students in the first cluster took part in economic-financial studies in secondary school. This ratio is lower in the other two clusters with $24.7 \%$ in the second and $23.3 \%$ in the third. During their higher education studies, those in the first cluster studied financial-economics subjects for 2.53 semesters on average, while this figure is 2.58 and 3 in the second and third clusters respectively. Secondary school financial-economics studies tend to be typical in the first cluster, while similar studies but in higher education in the third cluster.

Students in the first cluster spent 1.72 months on average studying/working abroad. This figure is 1.8 months in the second cluster, while those in the third spent the longest time abroad with 4.18 months. Regarding current work experience, we found that in the first cluster the dominant type of employment is part-time (34.8\%), with $18.3 \%$ working full time and $24.9 \%$ not working at all. In the second cluster, there is a higher ratio of students not working at all (28.8\%) and a lower ratio of those working part-time (31.2\%). The ratio of students not working at all is the lowest in the third cluster $(19.1 \%)$ and here less students work part-time (28.8\%) and full time (15.4\%), compared to the previous two groups. In the third group, the ratio of students receiving social benefits (child-care allowance, child-care benefit, unemployment benefit, etc.) is almost double the ratios of the other two clusters (27.4\%), which is in line with our findings on their demographics.

\subsection{The Goals of Young People}

The consumer and financial behaviour of young people are markedly influenced by their goals, which led us to include this topic in our research. Laying the foundations of their future is a predominant goal in all three clusters, with the highest 
ratio $(80.2 \%)$ in the third. Making friends and acquaintances as a goal had the highest ratio in the second cluster (34\%), where the goal of purchasing electrical goods is also the strongest (9.9\%) compared to the other two groups. Partying, travelling and adventures as a goal is also represented in the highest ratio (26.9) in the second cluster. At the same time goals, such as completing a semester successfully, getting a job, finding a partner for life, and laying the foundations of their future have the smallest ratio in the second cluster. The goal of completing a semester successfully is most pronounced in the first cluster (54.7\%). The goal of buying a car or a home is most predominant in the third group (24.6\%). All in all, we can say that the second cluster tends to choose short-term and adventure-oriented goals, while the first and the third focus on long-term objectives.

\subsection{Financial Awareness}

We asked the students to rate their financial knowledge on a scale of 1 to 7 . The average value for the whole sample is 4.3, which shows that undergraduates assessed their financial awareness with a medium score. However, there are significant differences between the average values of the clusters, with the second cluster having the lowest score (4.06) and the third the highest (4.54). Following the self-assessment, students had to answer several questions which tested their knowledge, therefore we could compare the results of the self-assessment and their actual knowledge. These results suggest that both the self-assessed and the actual knowledge is lowest in the second cluster and highest in the third.

The total sample shows that $71.9 \%$ of students have a realistic view of their financial knowledge, $6.4 \%$ underestimate and $21.7 \%$ overestimate themselves. When looking at the data by clusters, we see that in the second cluster the ratio of those who underestimate their financial knowledge is higher $(8.0 \%)$ than the sample average. The ratio of students with a realistic self-assessment is below the average in the second cluster $(69.2 \%)$, close to the average in the first (71.3\%) and over the average in the third $(74.9 \%)$.

\subsection{Collecting Information}

When making financial decisions, young people collect information from several sources (see Table 3). In the total sample, the most important source of information is the internet, followed by relatives.

Table 3. Sources of information for financial decisions

\begin{tabular}{llll}
\hline Source of information & Cluster 1 & Cluster 2 & Cluster 3 \\
\hline Relatives & 74 & 70.5 & 64.3 \\
Friends, acquaintances & 43.1 & 48.8 & 45.7 \\
Television, newspapers & 12.1 & 13.8 & 16.2 \\
Internet & 74.1 & 76.3 & 81.2 \\
Notices and publications in financial institutions & 29.1 & 28 & 36 \\
Financial advisor & 57.9 & 41.9 & 60.3 \\
Own experiences & 28.5 & 28.6 & 32.9 \\
\hline
\end{tabular}

Source: own editing

These two sources are represented in the same ratio in the first cluster, while in the other two, the internet was found to be more dominant. The comparison of the three groups shows that those in the third cluster are least likely to rely on relatives when looking for information for their financial decisions, but the internet is the most important source in this cluster. Also, notices and announcements of financial institutions, as well as banking staff and financial advisors are the most prevalent in this group. Relying on own experiences is represented in the same ratio in the first and second clusters, while it has the highest ratio in the third. Overall, we can say that students in the first and second clusters rely on the opinion of others (relatives, friends) more, while those in the third cluster tend to look for information on the internet, in notices, announcements themselves and also use their own experiences when making financial decisions.

\subsection{Banking Experiences}

Young people in the first cluster use the least amount of banking services (on average 2.2 services/person) and this figure is the highest in the third cluster (on average 2.6 services/person). There is a low ratio of new banking services (such as e-broker, smart phone apps), with only $2.1 \%$ of the total sample using e-brokers and $13.7 \%$ using smart phone apps. Student in the seconds cluster, however, were found to use these types of services to a larger degree (e-broker 3\%, smart phone apps $15.9 \%)$.

The average number of per capita bank accounts is lowest in the first (1.23) and highest in the third (1.27) cluster. 72.2\% of respondents had bank cards before starting their higher education studies. They use bank cards for several purposes. Some only use them for one, but others for as many as seven. The sample average of the purposes of bank card usage is 3.6, meaning that on average students use the bank cards for this many different purposes. The most diverse usage, similarly to banking services, is in the third cluster (on average 3.8). 


\subsection{Saving Experiences and Attitudes}

In this regard, we were interested in past and present experiences. $78.6 \%$ of undergraduates have some savings. Members of the first and third clusters have more savings compared to the sample average (87.6\% and $80.7 \%$ respectively), while this ratio is the lowest in the second cluster (56.8\%). Those who are unable to make savings usually explain this by not having enough income to cover even the most basic living expenses, however, other reasons, such as spending money for adventures or useless things are represented in a higher ratio in the second cluster.

We asked young people about the types of past savings goals. The results show that savings for short-term goals are fairly similar in the three groups, while savings for long-term goals reveal significant differences. Compared to the other two clusters, the third group had significantly more diverse long-term savings goals, which was also coupled with more experiences in past savings $(\mathrm{F}=6.545$, sig=0.001).

When we asked them about their present savings goals, we arrived at somewhat different findings. The present savings behaviour, which focuses on short-term goals, does not show any significant differences between the three groups. In contrast, savings behaviour regarding long-term goals is markedly different between the clusters and also different from past savings behaviour. The current behaviour reveals that the first cluster has the most diverse savings goals, while this was true for the third cluster in terms of past experiences. The average value of the second cluster is the lowest in this case also.

Most savings are kept in current accounts without deposits (43.1\% of the total sample). Students also tend to keep their savings at home $(29.5 \%)$ or in deposit accounts with a maturity of less than one year (17\%). They are less likely to choose maturity over 1 year for deposit accounts $(9.6 \%)$, building societies (7.6\%), investment funds (6.8\%) or government bonds $(3.4 \%)$.

Respondents do not tend to choose corporate securities, insurance products with a savings element or other financial instruments. Differences between the clusters were found in the following areas: compared to the sample average a higher ratio of students in the first group keep their savings in current accounts without deposits (47.4\%), at home (34.3\%) or in deposit accounts with a maturity of under $(20.1 \%)$ or over 1 year $(12.3 \%)$. Similarly, those in the third cluster keep their savings in building societies (10.9\%) and government bonds (4.9\%) in an above-average ratio.

\subsection{Loan Experiences and Attitudes towards Loans}

$54.8 \%$ of the respondents had in the past or currently have loans. This ratio is smaller in the first cluster (41.8\%), close to the sample average in the second (57\%) and higher in the third (73.9\%). The proportion of students with late/overdue repayment instalments was $7.4 \%$ in the first, $14 \%$ in the second and $23.8 \%$ in the third cluster. In the first cluster, the main reason for not taking out a loan was to avoid indebtedness $(40.1 \%)$, while in the second and third clusters respondents claimed in the largest numbers that they did not need a loan so far (31.6\% and $31 \%)$.

\section{Conclusion}

The three groups, segmented according to their financial attitudes and behaviour, were characterised using several variables, which made their initial description even more refined. Table 4 summarises all the variables of our research in all three segments. 
Table 4. Summary and interpretation of results

\begin{tabular}{|c|c|c|c|}
\hline & 1. Cluster 1 & 2. $\quad$ Cluster 2 & 3. $\quad$ Cluster 3 \\
\hline $\begin{array}{l}\text { Variables } \\
\text { examined }\end{array}$ & $\begin{array}{l}\text { CONSERVATIVES } \\
\text { 4. They claim to be financially } \\
\text { aware with high moral values and } \\
\text { a very low risk appetite. }\end{array}$ & $\begin{array}{l}\text { REBELS } \\
\text { 5. They have a lower level } \\
\text { of financial awareness, } \\
\text { greater willingness to take } \\
\text { risks and lower moral values. }\end{array}$ & $\begin{array}{l}\text { EXPERIENCED } \\
6 . \quad \text { They claim to be } \\
\text { financially aware with high } \\
\text { moral values and a very low } \\
\text { risk appetite. }\end{array}$ \\
\hline $\begin{array}{l}\text { Demographic } \\
\text { characteristics }\end{array}$ & $\begin{array}{l}\text { Average age: } 22.3 \text { years. } \\
\text { They usually live with their } \\
\text { parents. }\end{array}$ & $\begin{array}{l}\text { Average age: } 22.33 \text { years. } \\
\text { They usually live with their } \\
\text { parents. }\end{array}$ & $\begin{array}{l}\text { Average age: } 23.12 \text { years. } \\
\text { The ratio of them living in } \\
\text { their own home is higher } \\
\text { than the average. }\end{array}$ \\
\hline $\begin{array}{l}\text { Income and } \\
\text { income sources }\end{array}$ & $\begin{array}{l}\text { Their average income is EUR } 219 \text {, } \\
\text { which mainly comes from a } \\
\text { salary. }\end{array}$ & $\begin{array}{l}\text { Their average income is EUR } \\
239, \text { which mainly comes } \\
\text { from pocket money. }\end{array}$ & $\begin{array}{l}\text { Their average income is } \\
\text { EUR } 283 \text {, which mainly } \\
\text { comes from a salary. }\end{array}$ \\
\hline Goals & $\begin{array}{l}\text { Their main goals are to complete } \\
\text { the semester successfully, get a } \\
\text { job and find a partner for life. }\end{array}$ & $\begin{array}{l}\text { They have pronounced } \\
\text { short-term goals: to make } \\
\text { new friends, acquaintances } \\
\text { and have more adventures. }\end{array}$ & $\begin{array}{l}\text { Their main goals are } \\
\text { long-term: to buy a car and a } \\
\text { home, to lay the foundations } \\
\text { of their future. }\end{array}$ \\
\hline $\begin{array}{l}\text { Financial } \\
\text { awareness }\end{array}$ & Average & Low & High \\
\hline $\begin{array}{l}\text { Sources of } \\
\text { information for } \\
\text { financial decisions }\end{array}$ & Relatives, friends, internet & Relatives, friends, internet & $\begin{array}{l}\text { Several sources, especially } \\
\text { professional ones, but also } \\
\text { own experiences }\end{array}$ \\
\hline $\begin{array}{l}\text { Banking } \\
\text { experiences }\end{array}$ & They use a few services only. & $\begin{array}{l}\text { They are open to innovative } \\
\text { solutions. } \\
\text { They also choose new types } \\
\text { of services when using their } \\
\text { bank card. }\end{array}$ & $\begin{array}{l}\text { They use several services. } \\
\text { They use their bank cards for } \\
\text { a variety of purposes. }\end{array}$ \\
\hline $\begin{array}{l}\text { Loan experiences } \\
\text { and attitudes } \\
\text { towards loans }\end{array}$ & $\begin{array}{l}\text { They have a negative attitude } \\
\text { towards loans. The deterrent force } \\
\text { is that they do not want to become } \\
\text { indebted. }\end{array}$ & $\begin{array}{l}\text { Their attitudes towards loans } \\
\text { are not fully established. } \\
\text { They do not tend to worry } \\
\text { about indebtedness. }\end{array}$ & $\begin{array}{l}\text { They are not against loans. } \\
\text { They do not tend to worry } \\
\text { about indebtedness. }\end{array}$ \\
\hline $\begin{array}{l}\text { Savings } \\
\text { experiences }\end{array}$ & $\begin{array}{l}87.6 \% \text { have some kind of savings. } \\
\text { They typically keep their savings } \\
\text { in current accounts without } \\
\text { deposits, well hidden at home and } \\
\text { in bank deposits. }\end{array}$ & $\begin{array}{l}56.8 \% \text { have some kind of } \\
\text { savings. } \\
\text { They are more focused on } \\
\text { having new adventures and } \\
\text { having short-term goals } \\
\text { instead of making savings. }\end{array}$ & $\begin{array}{l}80.7 \% \text { have some kind of } \\
\text { savings. } \\
\text { More of them choose } \\
\text { building societies and } \\
\text { government bonds as a way } \\
\text { to save money. }\end{array}$ \\
\hline
\end{tabular}

Source: own editing

The first cluster mainly includes conservatives with a level-headed attitude, while those in the third cluster can be best characterised by being financially experienced and knowledgeable. The second group represents carefree students who live in the moment rather than focusing on the future, therefore, we call them rebels.

Our results reveal that undergraduates in Hungary are not homogeneous when it comes to financial attitudes and behaviour. Conservatives are consumers who have the lowest average income of the three groups and most of this income is from a salary. They claim to be more financially aware and tend to rely on their parents financially, while they have a more dismissive attitude towards loans. The reason for this negative attitude is to avoid indebtedness; this is their number one worry when it comes to loans. Simultaneously, they represent the largest proportion of students with savings compared to the other two groups. They are most likely to keep their savings at home or consider liquid or short-term solutions. They rely on friends and relatives for financial information and they have little experience. This means that they use fewer banking services compared to their fellow Hungarian undergraduates and, partly for the same reason, they have less experience with bank cards and loans. Their goals are less materialistic and mostly relate to studying, getting a job and finding a partner. Although they claim to have financial awareness, they often have conservative views, and their money attitude and habits are governed by their worries in some sense.

Rebels represent a segment of Hungarian undergraduates who are close to the Conservative group in average age, but have rather contrasting attitudes, since they are more adventurous and innovative. They are less financially aware, however, more willing to take risks and are more open-minded. They are less likely to consider not to overburden their parents 
financially. The main source of their income is pocket money, so they depend on their parents. The level of their financial knowledge is the lowest of the three groups. When they are in need of information, they get it from their immediate environment or the internet. Their goals are predominantly short-term and are focused mainly on acquiring new adventures and friends. While worries lead to a prudent and very cautious financial behaviour in the Conservative group, Rebels tend to be less anxious about their finances, which means that they are open-minded rather than careful with money. They do not have a clear view on loans yet, probably due to lack of experiences. This group has the lowest ratio of savings. Our findings suggest that they are best characterised by the "Carpe Diem" motto.

The segment of Experienced undergraduates is similar to the Conservatives in terms of financial awareness, risk appetite and moral values, but here students are more open to loans. This group has the highest average age and income. Similarly to the Conservative group, the main source of their income is their salary. They mostly have long-term goals, such as buying a car or a home. Consequently, their savings goals also include solutions for a longer term, such as buying a home. This group is strikingly different from the other two in terms of their wide-ranging experiences. These students have numerous experiences regarding information sources and the use of services and they use the available options in the most diverse way. While the lack of experiences among the Rebels contributes to the low level of financial literacy, the varied experiences of the Experienced group is coupled with a high level of financial knowledge.

There is a limited number of Hungarian studies on the financial attitude and behaviour of young people, which also discuss the relevance of attitudes or highlight the need to understand these attitudes in a greater depth (Nagy - Tóth, 2012; Zsótér - Nagy, 2012). Our study grouped undergraduates according to a less often applied criterion and the results clearly support the relevance of financial attitude as a criterion for segmentation.

Potential limitations to our survey could be that it focused on two higher education institutions in Hungary and undergraduates pursuing economics studies are overrepresented in our sample.

The segmentation of the three groups, however, can provide valuable information for the organisers of financial education programmes, as well as financial service providers.

The distinct differences in the attitudes and experiences of the three groups suggest that their financial education should be based on different foundations, which is worth considering when developing the relevant curricula. The Rebels, who are innovative, adventurous, but have little experience and financially rely on their parents would probably welcome different types of information and communication solutions compared to the Conservatives or the Experienced.

In our view, the Conservatives represent the biggest opportunity for intervention: these students need to be taught how to get information; considering that their worries are the driving force behind their financial decisions, it is crucial that they receive this information from credible sources. School education is perfectly suitable for this purpose if the information is passed on when the students are able to test this knowledge in practice (after finishing secondary school). If the students are properly informed, they are more likely to make financial decisions which will be beneficial to their own lives, as well as the national economy.

Since the Rebels are open-minded and have a larger risk appetite compared to the other two groups, they will acquire financial literacy most efficiently through modern communication channels (e.g. mobile apps). In their case school education most likely will not work (or even be counterproductive, leading to negative attitudes if the topic is forced on them). In addition to the above considerations, in their case it is not enough to teach them about financial products and solutions, but the environment in which this knowledge is passed on should also influence their mindset (from the short-term to the long-term perspective) while tapping into their "Carpe Diem" philosophy.

Last but not least, in the case of the Experienced, contrary to the other two clusters, conveying basic financial information is not necessary and will most probably lead to resistance. The best solution for them is to convey more complex information on the benefits and disadvantages of financial products, but tailored to the characteristics of their age.

\section{References}

Allen, M. W., Edwards, R., Hayhoe, C. R., \& Leach, L. (2007). Imagined interaction, attitudes towards money and credit, and family coalitions. Journal of Family and Economic Issues, 28, 3-22. https://doi.org/10.1007/s10834-006-9048-1

Béres, D., \& Huzdik, K. (2012). A pénzügyi kultúra megjelenése makrogazdasági szinten. (The Emergence of Financial Literacy at a Macroeconomic Level.) Public Finance Quarterly, 2012/3, 322-336.

Béres, D., Huzdik, K., Kovács, P., Sápi, Á., \& Németh, E. (2013). Felmérés a felsőoktatásban tanuló fiatalok pénzügyi kultúrájáról (Survey on the Financial Literacy of Young People in Higher Education). Research Report. Downloaded from:

http://www.asz.hu/tanulmanyok/2013/kutatasi-jelentes-felmeres-a-felsooktatasban-tanulo-fiatalok-penzugyi-kultur ajarol/t353.pdf 
Bhardwaj, S., \& Bhattacharjee, K. (2010). Modeling Money Attitudes to Predict Loan Default. The IUP Journal of Bank Management, 9, 12-20.

Botos, K. (2012). Pénzügyi kultúra és kockázatvállalás a közép-alföldi háztartásokban. (Financial Literacy and Risk Taking in Households in the Middle Great Plain Region.) Public Finance Quarterly, 2012/3, 291-309.

Chen, H., \& Volpe, R. P. (1998). An analysis of personal financial literacy among college students. Financial Services Review, 7, 107-128. https://doi.org/10.1016/S1057-0810(99)80006-7

Christopher, A. N., Marek, P., \& Carroll, S. M. (2004). Materialism and Attitudes Toward Money: An Exploratory Investigation. Individual Differences Research, 2(2), 109-117.

Danes, S. M., Huddleston, C. C., \& Boyce, L. (1999). Financial Planning Curriculum For Teens: Impact Evaluation. Financial Counseling and Planning, 10(1), 26-39.

Durvasula, S., \& Lysonsky, S. (2010). Money, money, money - how do attitudes toward money impact vanity and materialism? - The case of young Chinese consumers. Journal of Consumer Marketing. 27(2), 169-179. https://doi.org/10.1108/07363761011027268

Forman, N. (1987). Mind over Money. Doubleday. Toronto.

Furnham, A. (1984). Many sides of the coin: The psychology of money usage. Personality and Individual Differences, 5, 501-509. https://doi.org/10.1016/0191-8869(84)90025-4

Furnham, A. (1999). The saving and spending habits of young people. Journal of Economic Psychology, 20, $677-697$. https://doi.org/10.1016/S0167-4870(99)00030-6

Garman, E. T., \& Forgue, R. E. (2006). Personal finance. Boston: Houghton Mifflin.

Goldberg, H., \& Lewis, R. T. (1978). Money Madness: The Psychology of Saving, Spending, Loving and Hating Money. New York: William Morrow \& Co.

Habschick, M., Seidl, B., \& Evers, J. (2007). Survey of financial literacy schemes in the EU27 (VT Markt/2006/26H, Final Report). Downloaded from:

Hanti, S. (2011). Az e-banking és a bizalom kapcsolata Magyarországon a lakosság körében. (The Relationship between E-banking and Trust in Hungary among the Population.) In: Czakó, Á. - Husz, I. - Szántó, Z. (ed.): Meddig nyújtózkodjunk? - A magyar háztartások és vállalkozások pénzügyi kultúrájának változása a válság időszakában. (Should We Cut Our Coat According to Our Cloth? Changes in the Financial Literacy of Hungarian Households and Enterprises During the Time of the Crisis.) Budapest: BCE Innovációs Központ Nonprofit Kft., 5-6.

http://ec.europa.eu/internal_market/finservices-retail/docs/capability/report_survey_en.pdf"//ec.europa.eu/internal_ market/finservices-retail/docs/capability/report_survey_en.pdf

Inseng, H., \& Teichert, T. (2016). The Impact Of Generation Y Money Attitudes On Compulsive Buying: Contingency Effects Of Childhood Family Resources And Gender. Global Marketing Conference at Hong Kong Proceedings, 69-79. https://doi.org/10.15444/GMC2016.01.05.05

Jill, M., Norvilitis, J. M., \& Mendes, D.S. M. (2013). Attitudes toward Credit and Finances among College Students in Brazil and the United States. Journal of Business Theory and Practice, (1), 132-151.

Khare, A. (2016). Money attitudes, credit card and compulsive buying behaviour: a study on Indian consumers. International Journal of Business Competition and Growth, 5(1-3), 49-71. https://doi.org/10.1504/IJBCG.2016.079935

Klontz, B. T., \& Britt, S. L. (2012). How Clients' Money Scripts Predict Their Financial Behaviors. Journal of Financial Planning, 25(11), 33-43.

Luksander, A., Béres, D., Huzdik, K., \& Németh, E. (2014). Analysis of the Factors that influence the financial literacy of young people studying in higher education. Public Finance Quarterly, 59(2), 220-241.

Masuo, D. M., Malroutu, Y. L., Hanashiro, R., \& Kim, J. H. (2004). College Students' Money Beliefs and Behaviors: An Asian Perspective. Journal of Family and Economic Issues, 25(4), 469-481. https://doi.org/10.1007/s10834-004-5491-Z

McKenna, J. S., \& Nickols, S. Y. (1988). Planning for retirement security: What helps or hinders women in the middle years? Home Economics Research Journal, 17, 153-164. https://doi.org/10.1177/1077727X8801700204

Ministry of Human Resources. (2012). Statisztikai Tájékoztató Oktatási Évkönyv 2011/2012 (Statistical Yearbook of Education). Budapest: Ministry of Human Resources (today: Ministry of Human Capacities).

Nagy, P., \& Tóth, Z. (2012). Értelem és érzelem. A lakossági ügyfelek gazdasági magatartása és a bankokkal kapcsolatos 
attitüdjei. (Sense and Sensibility. Retail Customer Behaviours and Attitudes Towards Banks) Hitelintézeti Szemle, (Financial and Economic Review) Special issue, 13-24. Downloaded from: http://www.bankszovetseg.hu/wp-content/uploads/2012/10/13-24-ig-nagy-toth.pdf

Németh, E., \& Zsótér, B. (2017). Personality, Attitude and Behavioural Components of Financial Literacy: A Comparative Analysis. Journal of Economics and Behavioral Studies, 9(2), 46-57. https://doi.org/10.22610/jebs.v9i2.1649

Richins, M. L., \& Dawson, S. (1992). A consumer values orientation for materialism and its measurement: Scale development and validation. Journal of Consumer Research, 19, 303-316. https://doi.org/10.1086/209304

Rimple, M. (2017). Exploration of materialism and attitudes toward money in university students. The Journal of Indian Management \& Strategy, 22(2), 45-49. https://doi.org/10.1086/209304

Sajtos, L., \& Mitev, A. (2007). SPSS kutatási és adatelemzési kézikönyv. (Handbook of research and analysis with SPSS) Budapest: Alinea Kiadó.

Sundarasen, S. D. D., \& Rahman, M. S. (2017). Attitude Towards Money: Mediation To Money Management. Academy of Accounting and Financial Studies Journal, 21(1), 1-17.

Tang, T. L. P. (1992). The development of a short Money Ethic Scale: Attitudes toward money and pay satisfaction revisited. Personality and Individual Differences, 19(6), 809-816. https://doi.org/10.1016/S0191-8869(95)00133-6

Volpe, R., Chen, H., \& Liu, S. (2006). An Analysis of the Importance of Personal Finance Topics and the Level of knowledge Possessed by Working Adults. Financial Services Review, 15(1), 81-98.

Wang, X., \& Krumhuber, E. G. (2016). The love of money results in objectification. British Journal of Social Psychology, 56(2), 354-372. https://doi.org/10.1111/bjso. 12158

Yamauchi, K. T., \& Templer, D. I. (1982). The development of a money attitude scale. Journal of Personality Assessment, 46, 522-528. https://doi.org/10.1207/s15327752jpa4605_14

Zsótér, B. (2017). Apple from the tree... Intergenerational effects in young adults' financial socialization in family. Doctoral Dissertation. Corvinus University of Budapest, Hungary

Zsótér, B., \& Nagy, P. (2012). Mindennapi érzelmeink és pénzügyeink. A pénzzel kapcsolatos attitűdök és materiális irányultság szerepe a pénzügyi kultúra fejlesztésében, (Our everyday emotions and finances. The role money-related attitudes and materialistic orientation play in developing financial literacy). Public Finance Quarterly, 3, 310-321.

\section{Copyrights}

Copyright for this article is retained by the author(s), with first publication rights granted to the journal.

This is an open-access article distributed under the terms and conditions of the Creative Commons Attribution license which permits unrestricted use, distribution, and reproduction in any medium, provided the original work is properly cited. 